Nexus between population density and COVID-19 pandemic in the south Indian states: A geo-statistical approach

Mohammad Arif (Corresponding Author)

Department of Geography, Visva-Bharati (A Central University), Santiniketan, West Bengal, 731235, India

Email: $\underline{\text { arifaligs@gmail.com }}$

Soumita Sengupta

Department of Remote Sensing, Birla Institute of Technology, Mesra, Jharkhand, 835215, India

Email: soumitasengupta@gmail.com 


\section{Nexus between population density and COVID-19 pandemic in the south Indian states: A geo- statistical approach}

\section{Abstract \\ Background:}

The unprecedented growth of the novel coronavirus (SARS-CoV-2) as a severe acute respiratory syndrome escalated to the 2019 coronavirus disease (COVID-19) pandemic. It has created an unanticipated global public health crisis. The virus is spreading rapidly in India which poses serious threat to 135 crore population. Population density poses some unforeseen challenges to control the COVID-19 contagion. In times of crisis, data is crucial to understand the spatial relationship between density and the infection. The article study the district wise transmissions of the novel coronavirus in five south Indian states until $6^{\text {th }}$ June 2020 and its relationship with the respective population density.

\section{Methods:}

Data has been derived from COVID-19 India portal and Census of five different states. The five states are purposefully selected for better healthcare infrastructure visà-vis other states in India. The correlation of the population density and COVID-19 positive cases are evaluated using the statistical software and the district-wise data of COVID-19 infections and population density maps are produced in GIS environment.

\section{Results:}

We observed that corona virus spread depends on the spatial distribution of population density in three states especially in Tamil Nadu, Karnataka and Telangana. The results indicate that the long-term impacts of the COVID-19 crisis are likely to differ with demographic density.

\section{Conclusions:}

Policy initiatives aimed at reducing the health consequences of the COVID-19 pandemic should understand how vulnerabilities cluster together across districts.

Keywords: COVID-19, population density, south India, infections, GIS 


\section{Background}

COVID- 19 has been originated from Wuhan city of Hubei province in China. Covid19 stances for corona virus disease which has been first identified in 2019 and caused by extreme acute respiratory syndrome Coronavirus 2 (SARS-CoV-2). ${ }^{[1,2,3]}$ This virus disease rapidly circled all over the world and has been announced pandemic by the world health organization. ${ }^{[4,5]}$ More than 213 countries and territories have reported 6969079 confirmed COVID- 19 cases after china and thereafter it has been shifted in Europe and other countries. ${ }^{[6]}$ Thereafter this virus transmitted in the United States of America and Latin American countries. As for the number of patients diagnosed with the Corona virus, the USA is at the top of the list preceded by Brazil. ${ }^{[7]}$ Currently, the highest infected and deceased rate is in USA. Millions of people have been contaminated across the world, and many thousands have already died. Apart from direct diseases, this pandemic will affect almost every human being on Earth in one way or the other. ${ }^{[8]}$ The pandemic has triggered significant global socioeconomic disruption, such as postponing and cancelling sports, educational, political, and cultural events. ${ }^{[9]}$ The first confirmed case of the COVID-19 outbreak in India was registered in Thrissur district of Kerala state of south India on 30 January 2020, when a student arrived from China. ${ }^{[10]}$ After that, it has been transmitted most of the states throughout India. ${ }^{[1]}$ As of June 6, 2020, India has reported 246622 confirmed cases and 6946 deaths from coronavirus infection in 31 states and union territories. ${ }^{[12,13]}$

India is a vast country with varying climate, cultures, languages, employment and educational opportunities, culminating in distinct and complex patterns of interconnection between various areas. This country has the second largest population with 121 crore people next to China. ${ }^{[14]}$ The states of India vary widely in terms of population density. As per the Census of India 2011, the population density of India has 382 persons per square kilometre. ${ }^{[14]}$ Our study focuses on investigating the trend of COVID-19 and the population density analysis for the case of five south Indian states (Kerala, Karnataka, Tamilnadu, Telangana and Andhra Pradesh) which has developed healthcare systems to fight against COVID-19. Among these five states, Kerala has the highest population density with 860 persons per square kilometre. ${ }^{[14]}$. This diverse population density of five states has a different impact on the COVID-19 pandemic. On 22 March 2020 when cases rose, The Prime Minister of India declared a nationwide 21-day lockdown to reduce the effects of new coronavirus. ${ }^{[15]}$ To minimize the effect and spread of the novel coronavirus, lockdown operations are conducted across the country with rigorous restrictions on transport with human mobility and economic activity. Since there are no pharmaceutical medications in place or corona virus vaccines, a high transmission rate of this virus is expected, which will pose major challenges in controlling disease spread. ${ }^{[16]}$ 
Demographically Kerala, Karnataka, Tamilnadu, Telangana and Andhra Pradesh have emerged as an exception over the last few decades. ${ }^{[14,17]}$ These states have low birth rates and low death rates rather than other states of India. Population density, one of the foremost fundamental demographic attributes, could vary systematically with abstraction scale. According to the 2011 census, the population density in Kerala is 860 persons per sq. km. It is much higher than the level of 382 for all India. Next to Kerala is Tamilnadu state where every square kilometre is inhabited by 555 people. ${ }^{[14]}$ The remaining three states are Karnataka, Telangana and Andhra Pradesh have 319, 312 and 304 population density. ${ }^{[18,19]}$ The number of COVID-19 cases in Tamilnadu crossed 30000 as the total infections continued its upward trend till $6^{\text {th }}$ June 2020. ${ }^{[20]}$ Just over two months since its first COVID-19 case, Karnataka state has reported 5103 positive corona cases. ${ }^{[21]}$ In the Telangana State, the surge in COVID-19 cases continued with the total number of people affected to $3496 .{ }^{[22]}$ Coronavirus is spreading in Andhra Pradesh despite the lockdown with a total number of positive cases is 3588. ${ }^{[23]}$ Among the all south Indian states, Kerala has reported the least number of positive cases with only 1807 infections in 14 districts. ${ }^{[24]}$ Kerala has a high-quality public health infrastructure among all other states of India. However, the number of cases is increasing as mentioned in figure 1 which is an alarming situation for these five states. ${ }^{[12]}$

In the wake of the latest COVID-19 crisis, one of the most pressing issues is to gain a better understanding of the corona positive cases in which population density has determined different patterns in South Indian states. It is evident that cities with high population density have a large number of corona positive cases. ${ }^{[25,26]}$ This study contributes to ongoing COVID-19 monitoring efforts by identifying reported cases with population density at the district level. Spatial analysis has been done in GIS environment for the evaluation and distribution of COVID-19 cases and the density of districts. Our current and potential analysis can be resumed every day as new data are available to detect new emerging zones and focus on areas where transmission decreases or increases. 


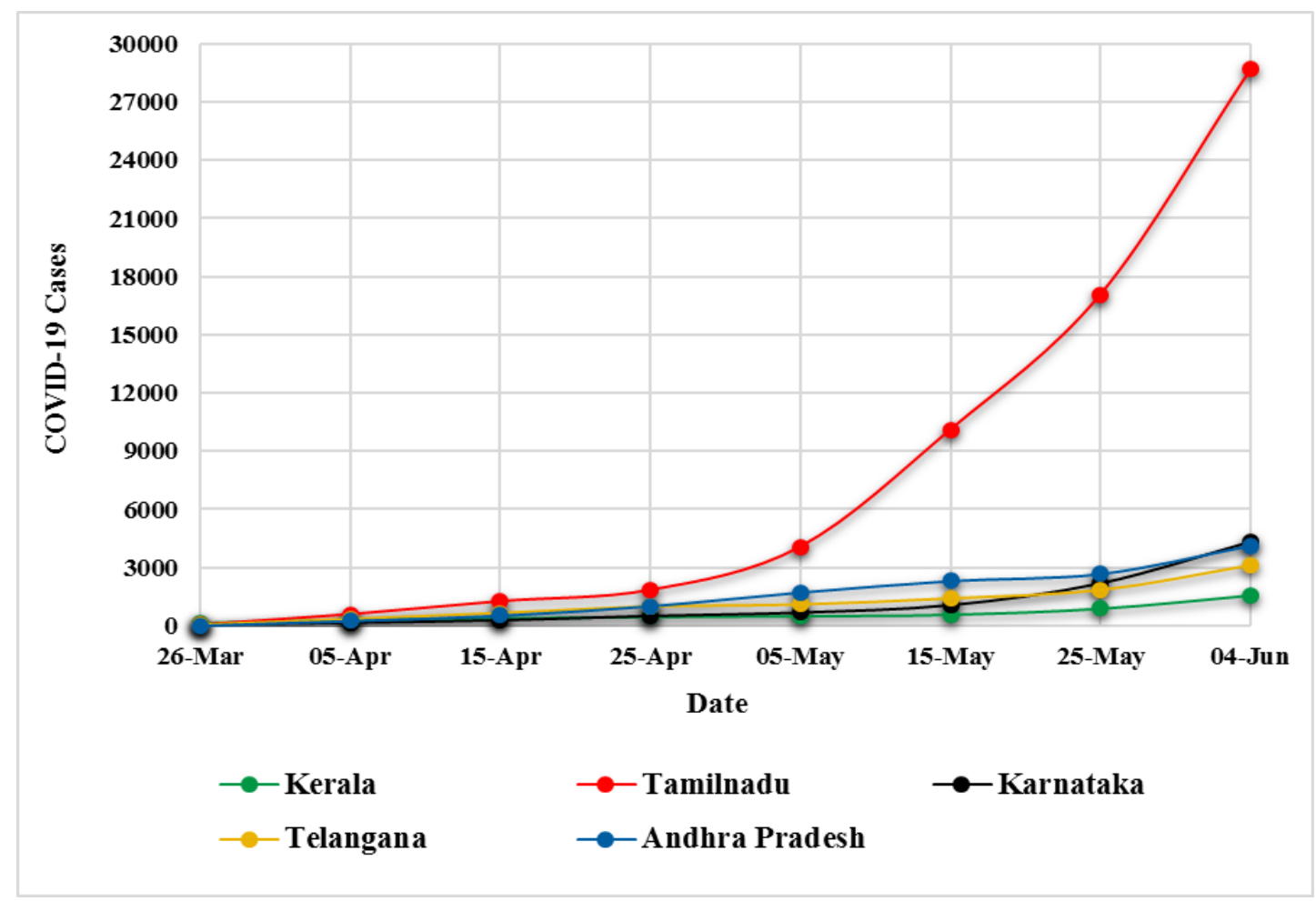

Figure 1. Trend of COVID-19 in five south Indian states

Data source: Ministry of Health \& Family Welfare, Government of India and prepared by authors

\section{Methods}

\section{Data used}

In this study, we made an attempt to correlate population density with the number of COVID-19 positive cases in different districts of south India. The present research work based on secondary sources of information. Data regarding corona virus cases has been collected from Covid-19 India portal and Ministry of Health \& Family Welfare as of 10th May 2020. Population density data of Kerala, Karnataka and Tamilnadu states has been collected from the Census of India 2011. Remaining two states, Telangana and Andhra Pradesh population density data retrieved from Statistical Year Book 2017 (Directorate of Economics and Director Statistics, Telangana) and Districts at a Glance, Andhra Pradesh 2018 (Directorate of Economics and Statistics, Andhra Pradesh) respectively. The districts have been taken as the unit of analysis. Fourteen districts from Kerala, thirty eight districts from Tamilnadu, thirty districts from Karnataka, thirty three districts from Telangana and thirteen districts from Andhra Pradesh have been included in the analysis.

\section{Methodology}


The correlation of the population density and COVID-19 positive cases are evaluated using the $\mathrm{R}$ statistical software and the district-wise data of COVID-19 infections and population density maps are produced in GIS environment using ArcGIS software. ${ }^{[28]}$ The inter-district variation are grouped into five categories i.e. very low, low, medium, high and very high. Pearson correlation coefficient has been applied to examine the association between the number of COVID-19 infected cases and population density. The correlation coefficient has been calculated by the following equation:

Correlation coefficient: Correlation is a statistical method that determines the degree of relationship between two different variables. A correlation coefficient is a numerical measure of a statistical relationship between two variables. One of the most important features of the correlation coefficient is it can only range from -1.00 to +1.00 . Therefore, normalization of the data was done in $\mathrm{R}$ statistical. If the correlation coefficient approaches $r=+1.00$ (or greater than $r=+.50$ ) it depicts a strong positive relationship or a high degree of relationship between the two variables. If the correlation coefficient approaches $r=-1.00$ (or less than $r=-.50$ ), it refers that there is a strong negative relationship. If the correlation coefficient approaches $r=0.00$, it indicates that there is no correlation between the two variables. After normalization of all data sets, a correlation study was carried out using the 'Pearson Product-Moment Correlation Coefficient' to measure the degree of relationship between two continuous variables. ${ }^{[29]}$ The Pearson's coefficient $r$ was obtained using the following formula in R statistical:

$\mathbf{r}=\frac{\mathbf{n} \sum \mathbf{X Y}-\sum \mathbf{X} \cdot \sum \mathbf{Y}}{\sqrt{\mathbf{n} \sum \mathbf{X}^{2}-\left(\sum \mathbf{X}\right)^{2}} \cdot \sqrt{\mathbf{n} \sum \mathbf{Y}^{2}-\left(\sum \mathbf{Y}\right)^{2}}}$

Where, $n=$ number of pairs of score

$\sum \mathbf{X}=$ sum of $\mathbf{x}$ scores

$\Sigma \mathbf{Y}=$ sum of y scores

$\sum \mathbf{X Y}=$ sum of the products of paired scores

$\sum \mathbf{X}^{2}=$ sum of squared $\mathrm{x}$ scores

$\sum \mathbf{Y}^{2}=$ sum of squared y scores

After computing the $\mathrm{r}$ value for a specified data set, a test was done to check the significance of the Correlation Coefficient. A two-tailed test of significance was carried out. Thus, the value of $r$ and the number of pairs of scores were converted through a formula into a distribution called the ' $t$ ' distribution. The ' $t$ ' formula was deliberately used to test whether $r$ is equal to zero. The formula used for' $t$ ' test was: 


$$
\mathbf{t}=\mathbf{r} / \sum\left(\mathbf{1}-\mathbf{r}^{2}\right) /(\mathbf{n}-\mathbf{2})
$$

Where $\mathrm{r}=$ correlation coefficient and $\mathrm{n}=$ the number of pairs of scores.

Degree of freedom: Degrees of freedom describes the number of independent values that a statistical analysis can estimate. It was measured by $\mathrm{N}-2$ where $\mathrm{N}$ is the number of pairs of scores.

Scatterplot has done in Microsoft Excel to represent the relationship between two numerical variables. One variable was chosen in the horizontal axis and another in the vertical axis. Here, 'Population Density' was used in the horizontal axis and 'Covid19 Positive Cases' was used in the vertical axis to plot the diagram for the representation of the data sets.

\section{Why South Indian states?}

Health inequalities exist in India due to the unequal distribution of health services across the States. India's healthcare infrastructure is unable to cope with the present COVID-19 crisis. The major problems are shortages in medical supplies and a failure to provide adequate testing. This study examined health infrastructure focusing on hospital beds in five south Indian states. In India, there are 18, 99,228 hospital beds and 1.13 beds per thousand which includes government and private hospitals. According to the latest Health Index report, ${ }^{[27]}$ Kerala state has arisen as the best healthcare infrastructure in India. Tamilnadu and Karnataka state have a poor capacity than the national average. However, Andhra Pradesh and Telangana state have poor capacity of hospital beds per thousand persons. Overall, southern India has a better capacity to serve patients. But still, it is insufficient to fight this pandemic with the current amount of resources.

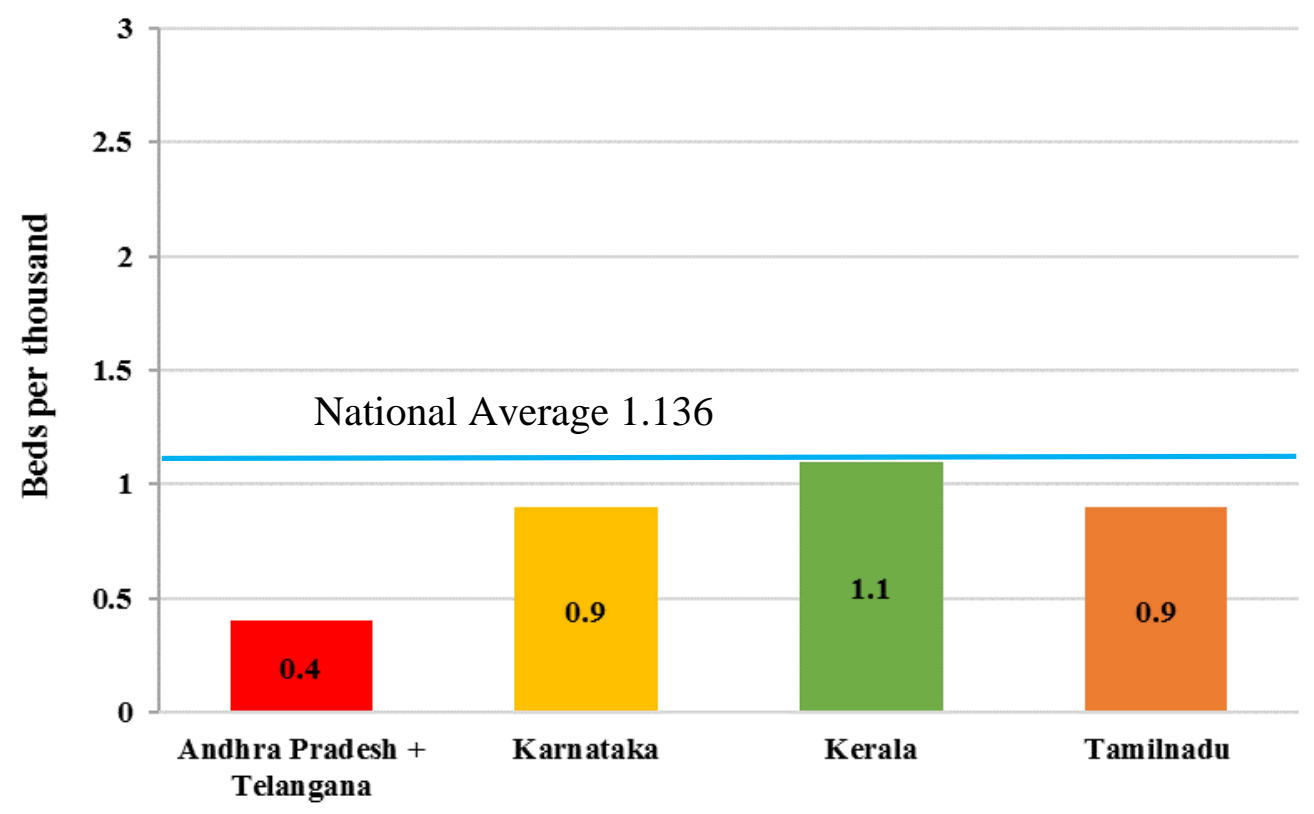

Figure 2. Beds Available per Thousand in the south Indian States

Data source: Ministry of Health \& Family Welfare, GOI and prepared by authors 
Table 1. Present healthcare infrastructure in south Indian states in comparison the India

\begin{tabular}{|c|c|c|c|c|c|c|}
\hline States & $\begin{array}{l}\text { Numbe } \\
\mathrm{r} \quad \text { of } \\
\text { districts }\end{array}$ & $\begin{array}{l}\text { Populatio } \\
\text { n density }\end{array}$ & $\begin{array}{l}\text { Total } \\
\text { number } \\
\text { of } \\
\text { hospitals } \\
\text { (public + } \\
\text { private) }\end{array}$ & $\begin{array}{l}\text { Percentage } \\
\text { of } \\
\text { hospitals } \\
\text { in India }\end{array}$ & $\begin{array}{l}\text { Total } \\
\text { number of } \\
\text { hospitals } \\
\text { beds } \\
\text { (public + } \\
\text { private) }\end{array}$ & $\begin{array}{l}\text { Percentag } \\
\text { e of beds } \\
\text { in India }\end{array}$ \\
\hline Kerala & 14 & 860 & 3342 & 4.82 & 99,227 & 5.22 \\
\hline Tamilnadu & 38 & 555 & 2439 & 3.52 & $1,55,375$ & 8.18 \\
\hline Karnataka & 30 & 319 & 10684 & 15.42 & $2,62,109$ & 13.80 \\
\hline Telangana & 33 & 312 & 4110 & 5.93 & 99,919 & 5.26 \\
\hline $\begin{array}{l}\text { Andhra } \\
\text { Pradesh }\end{array}$ & 13 & 304 & 928 & 1.34 & 83,230 & 4.38 \\
\hline $\begin{array}{l}\text { Total in } \\
\text { India }\end{array}$ & 739 & 382 & 69265 & & $18,99,228$ & \\
\hline
\end{tabular}

Source: Central Bureau of Health Intelligence, Ministry of Health \& Family Welfare, Government of India, 2019 and Tabulated by authors

Kerala is located within the southwestern end of the Indian landmass. Kerala is bordered to the south and east by Tamil Nadu, to the north and northeast by Karnataka. The tropical climate and the rich monsoons offer beautiful landscapes, ample bodies of water, long beaches and over 40 rivers add to the charm. Popular by the name "God's Own Country", the location of Kerala is geographically located between $74^{\circ} 27^{\prime}$ to $77^{\circ} 37^{\prime}$ north latitudes and $8^{\circ} 17^{\prime}$ to $12^{\circ} 47^{\prime}$ east longitudes. The population in Kerala is 33,406,061 according to Provisional Population Figures 2011. ${ }^{[14]}$ Kerala is home to nearly 3 percent of India's population and its land is three times denser than the rest of India.

Tamil Nadu is India's 11th largest state in terms of size, and the country's third largest urbanized population. The state, with a population of 72,138,958 (Census 2011), is the seventh most populated state in the country and covers an area of 130,058 sq.km. This state is bounded by Andhra Pradesh and Karnataka on the north, Kerala on the west, the Bay of Bengal on the east and the Indian Ocean on the south. Tamilnadu extends with a geographical extent between $8^{\circ} 5^{\prime}$ and $13^{\circ} 35^{\prime}$ North and $76^{\circ} 15^{\prime}$ and $80^{\circ} 20^{\prime}$ east. $^{[14]}$ 
Karnataka is located in the southwestern part of India. It shares its boundaries with the southwest Kerala, northwest Goa, southeast Tamilnadu and east Andhra Pradesh. In terms of population, Karnataka ranks ninth in India. According to Census 2011, Karnataka has a population of 6.11 Crores. The total geographical area of the state is 191,791 square $\mathrm{km}$. Karnataka State is situated at $11^{\circ} 30^{\prime}$ to $18^{\circ} 30^{\prime}$ North latitudes and $74^{\circ}$ to $78^{\circ} 30^{\prime}$ East longitude. ${ }^{[14]}$

Telangana state was carved out of the earlier Andhra Pradesh and established in the Indian Union as the twenty ninth state with a geographic area of 1,12,077 sq. km. Telangana is found on the Deccan highland and lies within the Southern region of India. The State is surrounded by the Maharashtra state to the north, Chhattisgarh to the north, Karnataka to the west and Andhra Pradesh to the south and east. The total population of the state is about 3.50 crore as per the Census 2011. Telangana stretches from $16^{\circ} 30^{\prime}$ to $18^{\circ} 20^{\prime}$ northern latitudes and $77^{\circ} 30^{\prime}$ to $79^{\circ} 30^{\prime}$ eastern longitudes. ${ }^{[18]}$

Andhra Pradesh state is located in the southeastern part of the Indian subcontinent. It is delimited to the south by the Indian states of Tamil Nadu, to the southwest and west by Karnataka, to the northwest by Telangana and to the northeast by Odisha. The state includes a substantial portion of the Eastern Ghats and the eastern part of the Deccan plateau. The total population of the State is 49,386,799, with a geographical area of $162,975 \mathrm{~km}$, according to census 2011. Andhra Pradesh lies between latitude $12^{\circ} 41^{\prime}$ to $19^{\circ} 07^{\prime} \mathrm{N}$ and longitude $77^{\circ}$ to $84^{\circ} 40^{\prime} \mathrm{E}^{[19]}$
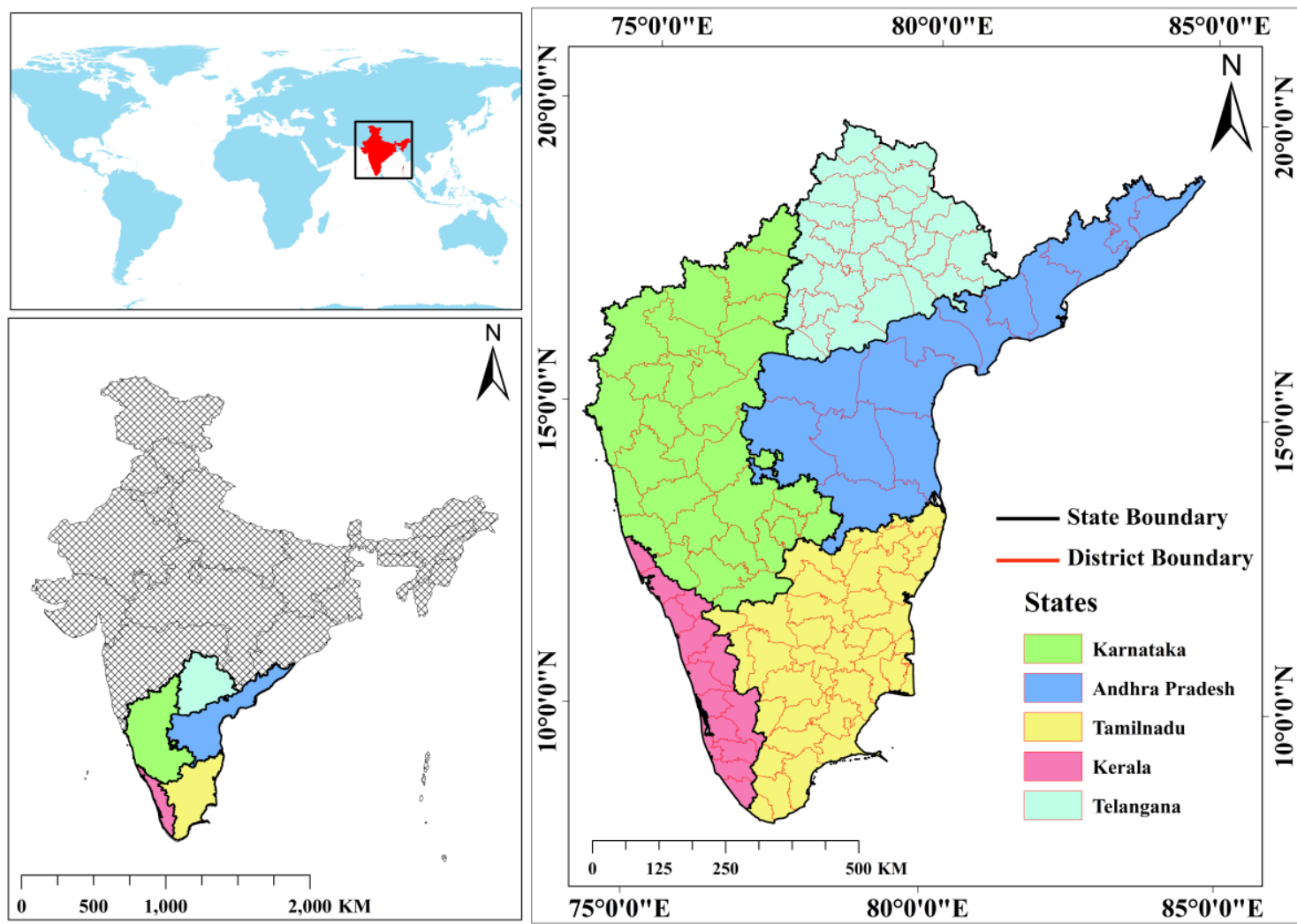
Figure 3. Location map of the study area

Prepared by authors

\section{Results}

The recent COVID-19 infections have triggered major health burdens in many states across the India ${ }^{[30]}$. COVID-19 cases in India are well over 246622 as of $6^{\text {th }}$ June 2020. It is found that Tamilnadu has the highest corona positive cases followed by Karnataka and Telangana state. Among all five south Indian states, Kerala has the lowest positive cases and Andhra Pradesh has the highest rate of recovery for coronavirus infections. However, the mortality rate is very low in south Indian states in comparison to the country. The whole south India regulates the pandemic more deftly than the other Indian states. Cases have risen sharply in Tamil Nadu, but mortality is relatively under low. In Andhra Pradesh, only 73 persons have lost their lives and Karnataka, another powerful COVID-19 fighter, with over 5103 reports, is witnessing 57 fatalities. Our main aim was to compare all district wise covid-19 cases with the relation of demographic density in all 5 states. Table 2 depicts the overall scenario of corona virus affected south Indian states with comparison to India.

Table 2. Sate-wise breakdown of total positive, recovered and deceased cases of COVID-19

\begin{tabular}{|l|l|l|l|l|l|}
\hline States & $\begin{array}{l}\text { Total Covid- } \\
19 \quad \text { positive } \\
\text { cases }\end{array}$ & $\begin{array}{l}\text { Total cases } \\
\text { Recovered }\end{array}$ & $\begin{array}{l}\text { Percentage } \\
\text { of } \\
\text { recovered }\end{array}$ & $\begin{array}{l}\text { Total cases } \\
\text { deceased }\end{array}$ & $\begin{array}{l}\text { Percentage } \\
\text { of } \\
\text { deceased }\end{array}$ \\
\hline Kerala & 1807 & 762 & 42.17 & 15 & 0.83 \\
\hline Tamilnadu & 30152 & 16395 & 54.37 & 251 & 0.83 \\
\hline Karnataka & 5103 & 1523 & 29.85 & 57 & 1.12 \\
\hline Telangana & 3496 & 1710 & 48.91 & 123 & 3.52 \\
\hline $\begin{array}{l}\text { Andhra } \\
\text { Pradesh }\end{array}$ & 3588 & 2323 & 64.74 & 73 & 2.03 \\
\hline $\begin{array}{l}\text { Total in } \\
\text { India }\end{array}$ & 246622 & 118632 & 48.1 & 6946 & 2.82 \\
\hline
\end{tabular}

Data source: Covid-19 India portal and Ministry of Health \& Family Welfare, Government of India and tabulated by authors

A Pearson correlation was conducted to explore the relationships between the population density and COVID-19 positive cases for south Indian states. As shown in Table 3, the results revealed that a significantly large and positive association between density and Covid-19 cases in Tamilnadu [where $r(36)=0.99$ ] and Telangana states 
[where $\mathrm{r}(31)=0.99$ ]. However, a positive correlation was observed between the population density and COVID-19 positive cases in Karnataka state [where r (28) = 0.29]. It is also worth noting that there was a negative but statistically insignificant association between these two variables for the state of Kerala. The relationships between COVID-19 cases and population density for Andhra Pradesh state have shown statistically insignificant [where $\mathrm{r}(11)=0.003$ ].

Table 3. Tracking the Association between population density and covid-19 cases using Pearson Correlation Coefficient for south Indian states

\begin{tabular}{|l|l|l|l|l|l|}
\hline State & $\begin{array}{l}\text { Test } \\
\text { statistic }(\mathbf{t})\end{array}$ & $\begin{array}{l}\text { Degree of } \\
\text { freedom } \\
(\mathbf{d f})\end{array}$ & $\mathbf{p}$ value & $\begin{array}{l}\text { 95 percent } \\
\text { confidence } \\
\text { interval }\end{array}$ & $\begin{array}{l}\text { Correlation } \\
\text { co-efficient }\end{array}$ \\
\hline Kerala & -0.21828 & 12 & $0.8309 * * *$ & $\begin{array}{l}-0.5743050, \\
0.4838352\end{array}$ & -0.0628 \\
\hline Tamilnadu & 68.412 & 36 & $\begin{array}{l}<2.2 \mathrm{e}- \\
16^{* * *}\end{array}$ & $\begin{array}{l}0.9925956, \\
0.9980269\end{array}$ & 0.9961 \\
\hline Karnataka & 1.6328 & 28 & $0.1133^{* * *}$ & $\begin{array}{l}-0.07153725, \\
0.58441198\end{array}$ & 0.2901 \\
\hline Telangana & 47.391 & 31 & $\begin{array}{l}<2.2 \mathrm{e}- \\
16 * * *\end{array}$ & $\begin{array}{l}0.9860767, \\
0.9966548\end{array}$ & 0.9931 \\
\hline Andhra & 0.0099614 & 11 & $0.9922^{* * *}$ & $\begin{array}{l}-0.5488902, \\
0.5530735\end{array}$ & 0.003 \\
Pradesh & & & & & \\
\hline
\end{tabular}

$\mathrm{p}<0.05^{* * *}$

Source: Prepared by authors

\section{Discussion}

We have conducted a spatial study in different districts of five south Indian states and found that Tamilnadu, Telangana and Karnataka has positive relation between population density and COVID-19 positive cases. Remaining two states, Kerala and Andhra Pradesh has no association between these two indicators.

\section{Kerala state}

As of June 6, 2020, Kerala, a high population density state, has already recorded 1807 confirmed COVID-19 cases. Most of the corona affected patients are mainly found in the northern part of Kerala. Kannur and Kasaragod districts have maximum positive cases. This state has done a remarkable job that $95 \%$ of those infected have completely recovered with a case fatality rate of $0.78 \%$ till $10^{\text {th }}$ May, 2020. After that, corona cases started to increase in different parts of the state due to international migration. ${ }^{[24]}$ However death rate is low as compared to the national average $2.82 \%$. 
In order to understand the influence of population density, we performed Pearson correlation using the COVID-19 data. However, a negative relationship is seen between these two variables. So COVID-19 positive incidents happened without any relation to the population density of different districts. Kerala government COVID-19 portal indicates that the international migration factor induced the positive cases. ${ }^{[24]}$ The choropleth map of figure $4 \mathrm{a}$ is depicting a districtwide variation of density and corona cases. In order to understand the correlation, we have shown a scatter plot for better representation.

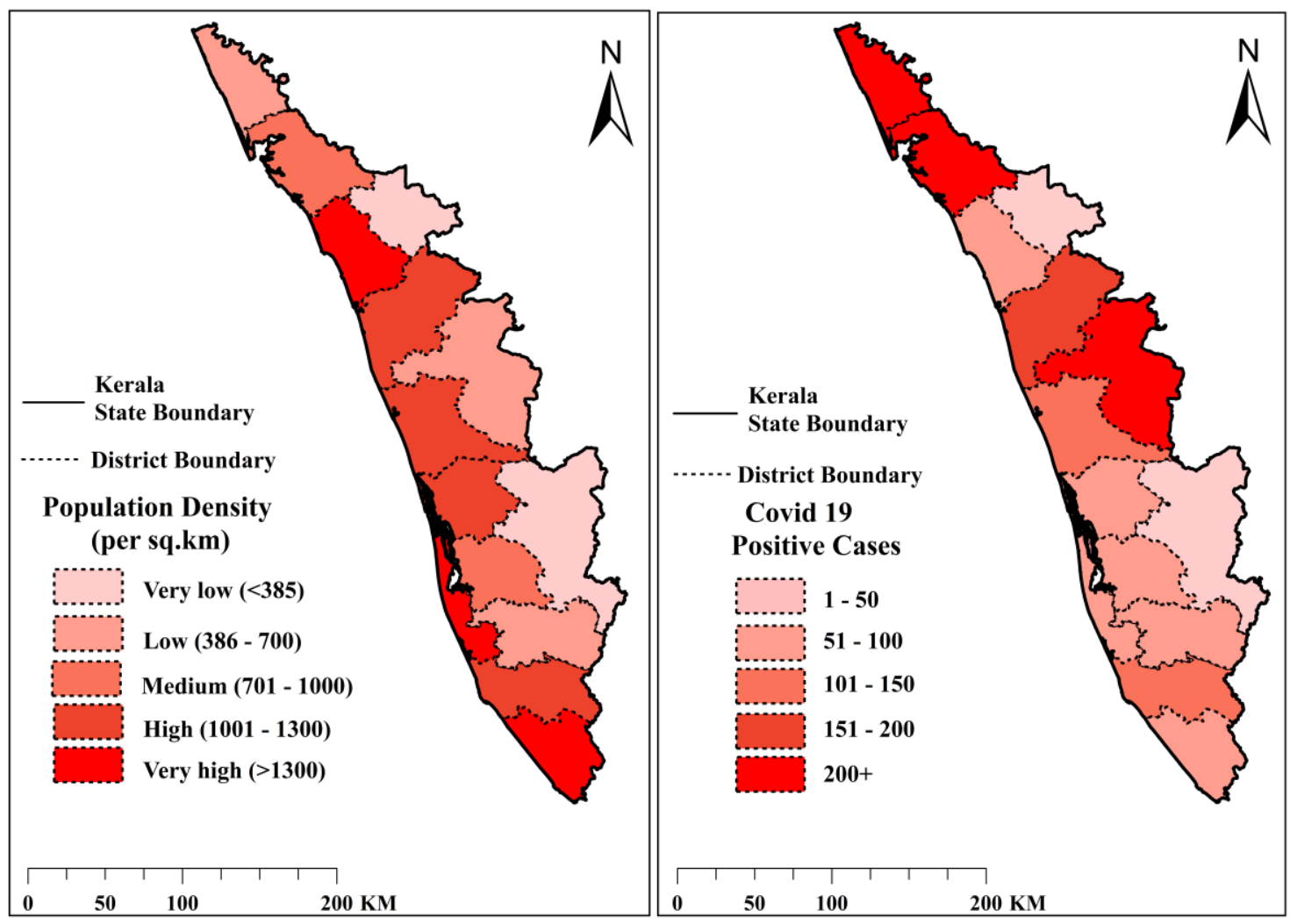

Figure 4a. Spatial distribution of population density and COVID-19 cases in Kerala state 


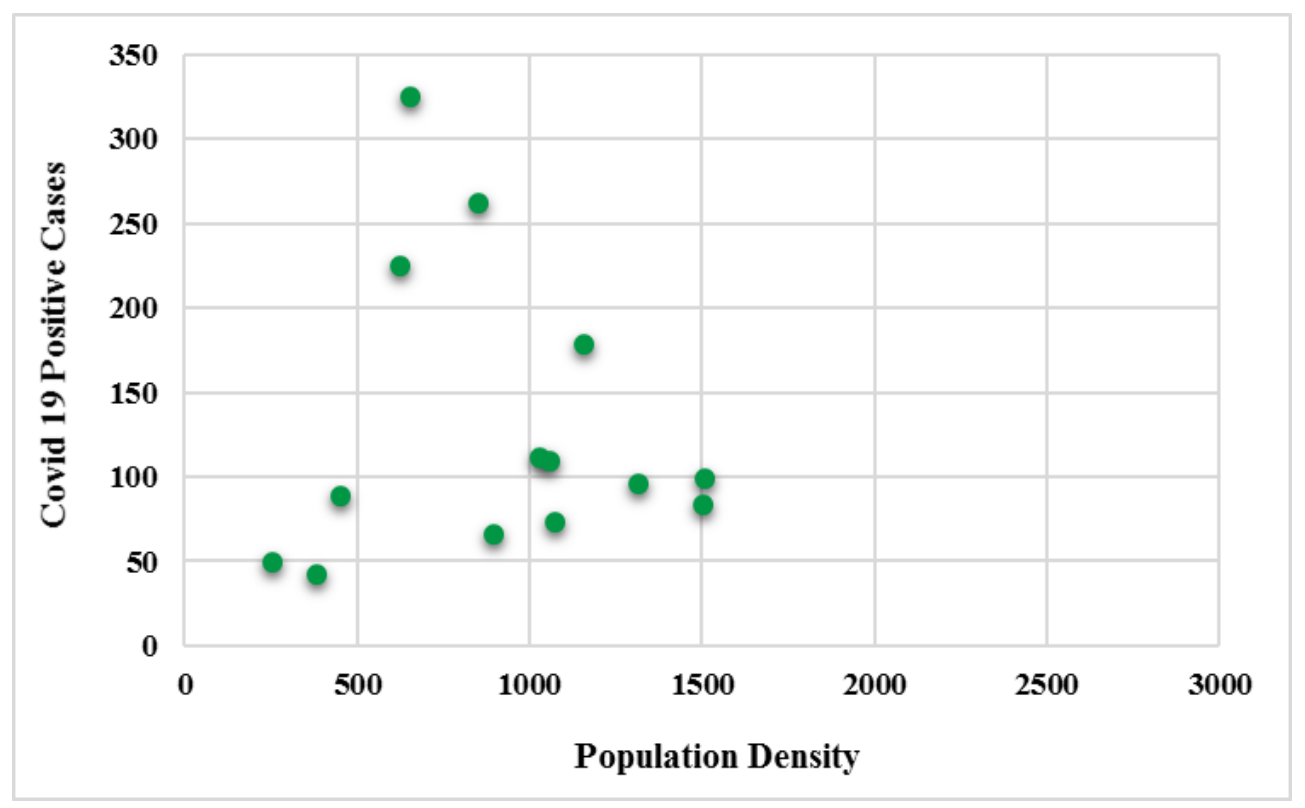

Figure 4b. Scatter plot between population density and covid-19 cases for Kerala state

Source: Prepared by authors

\section{Tamilnadu state}

Tamilnadu has recorded 30152 corona positive cases which is the highest number in south India. According to the state health bulletin, the Chennai district alone reported 20993 cases of corona virus in the whole state which have a population density of 26553 persons per square $\mathrm{km}$. The North Chennai Koyambedu market has identified as the recent hotspot of COVID-19. ${ }^{[31]}$ Near about 2,000 cases were related to the popular market of Chennai. Like Kerala, this state also has a very low mortality rate of about $0.83 \%$. Data represented in table 8 shows the positive correlation between the population density and the number of covid-19 cases. Following figure 5a clearly depicts the spatial analysis between density and corona infections in different districts of the Tamilnadu. 


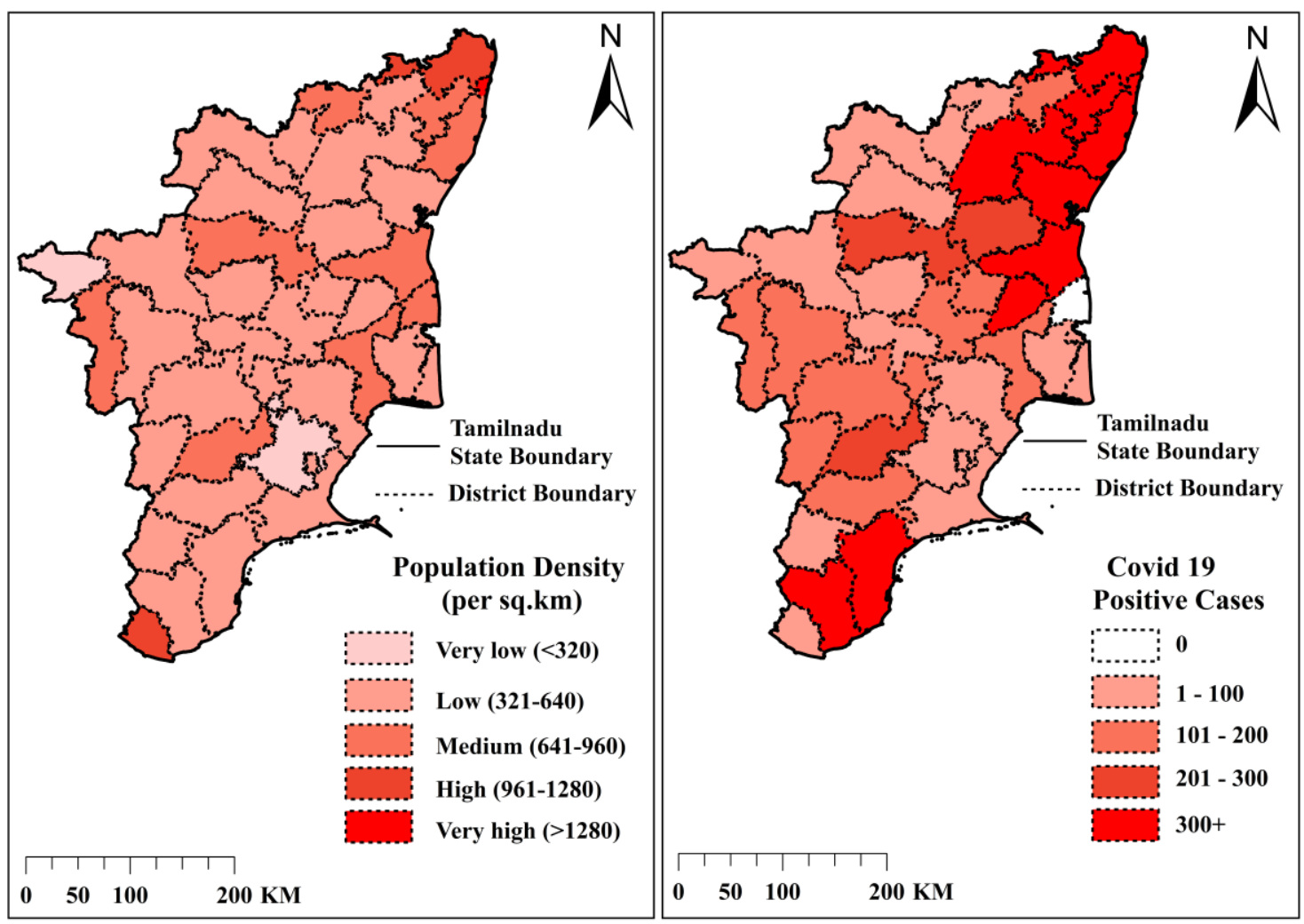

Figure 5a. Spatial distribution of population density and COVID-19 cases in Tamilnadu state

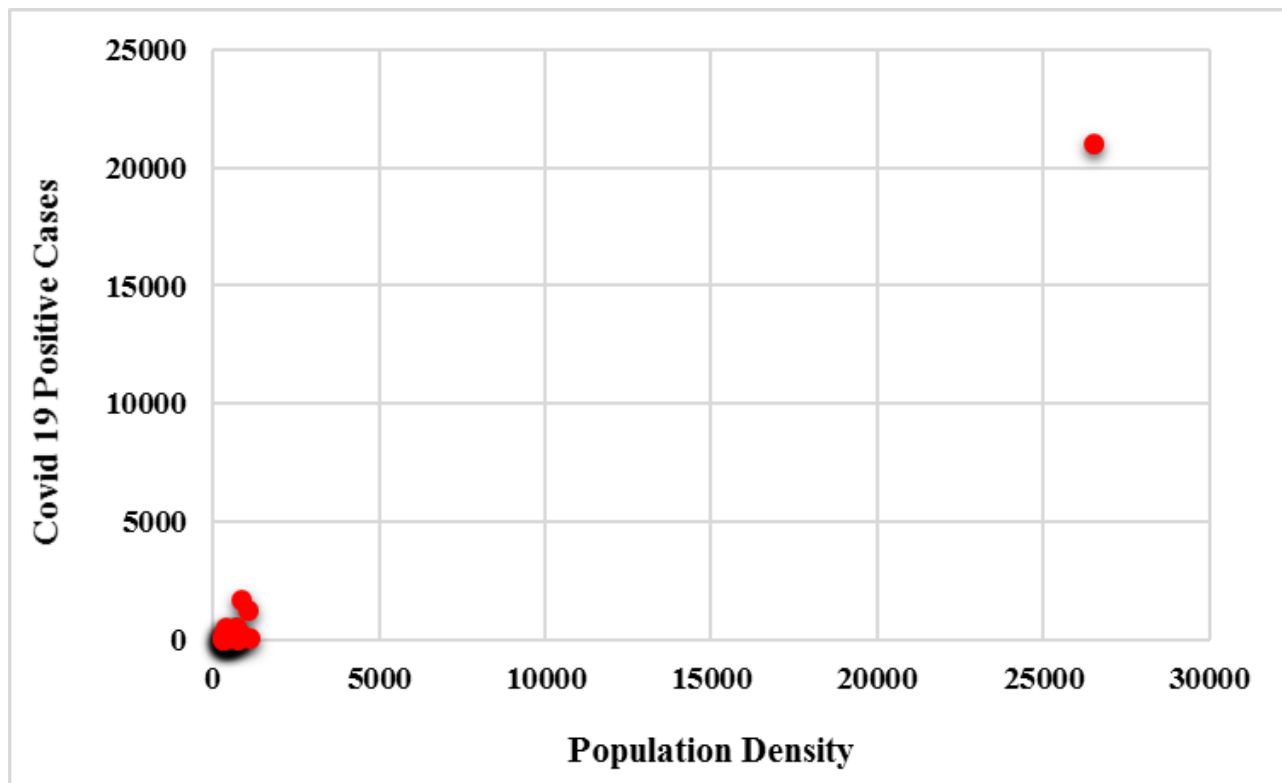

Figure 5b. Scatter plot between population density and covid-19 cases for Tamilnadu state

Source: Prepared by authors 


\section{Karnataka state}

After Tamilnadu state, Karnataka has highest number of Covid-19 cases which is about 5103. Kalaburgi, Udupi, Yadagiri and Mandya districts has kept the Karnataka government on its toes due to sharp surge in the number of Covid-19 cases. Till $10^{\text {th }}$ May, Bangalore Urban district has the highest COVID-19 cases but now Udupi is most infected district among the state. ${ }^{[32]}$ The recovery rate in the state is at 29.85 percent and the fatality rate is 1.12 percent. From figure $6 \mathrm{a}$, it is clearly found that, districts of northern Karnataka have more corona cases rather than southern Karnataka. As of $6^{\text {th }}$ June 2020, about 29 districts out of 30 districts have been contaminated with corona in Karnataka state. Table 3 indicated a positive association between population density and COVID-19 cases.

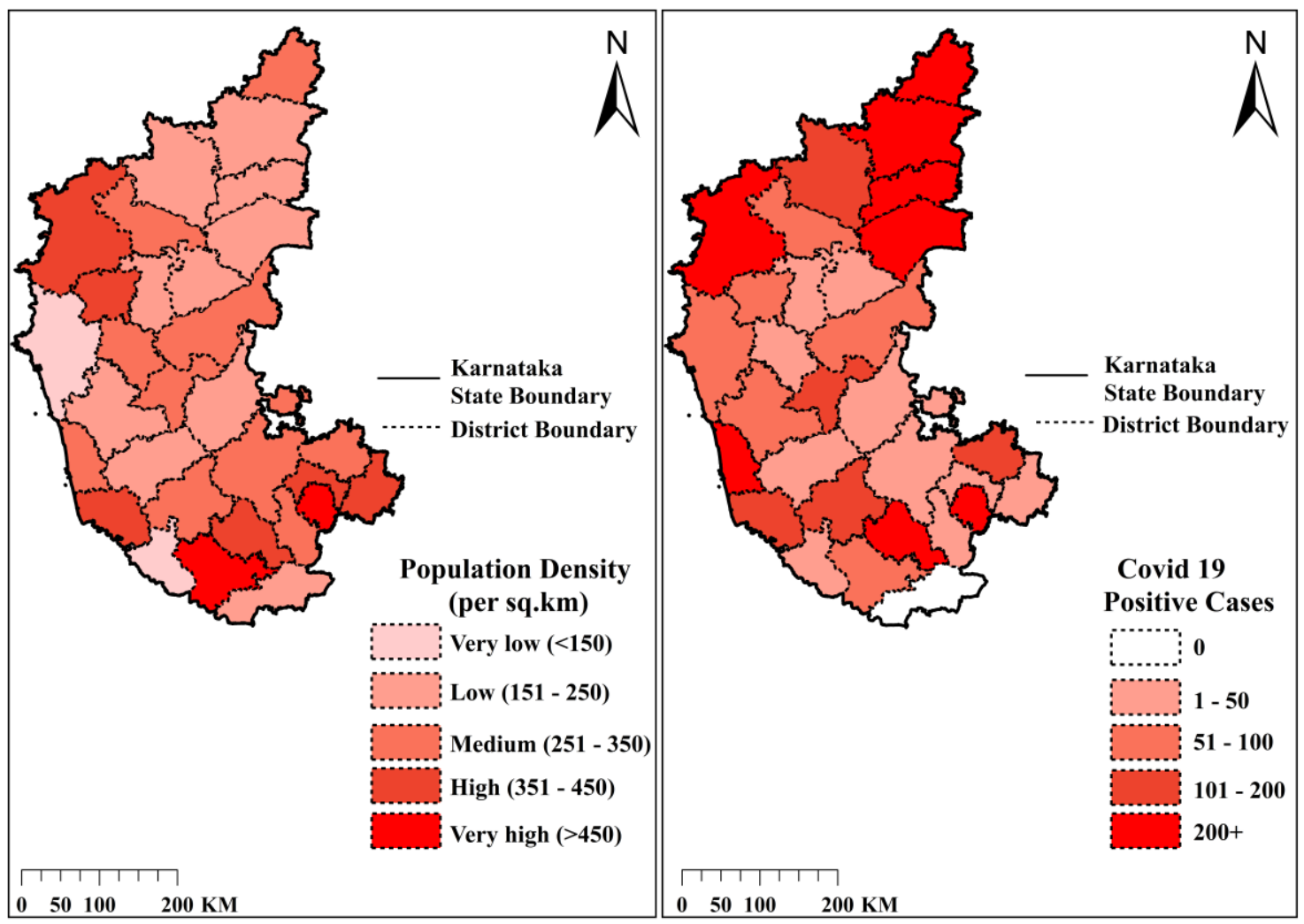

Figure 6a. Spatial distribution of population density and COVID-19 cases in Karnataka state 


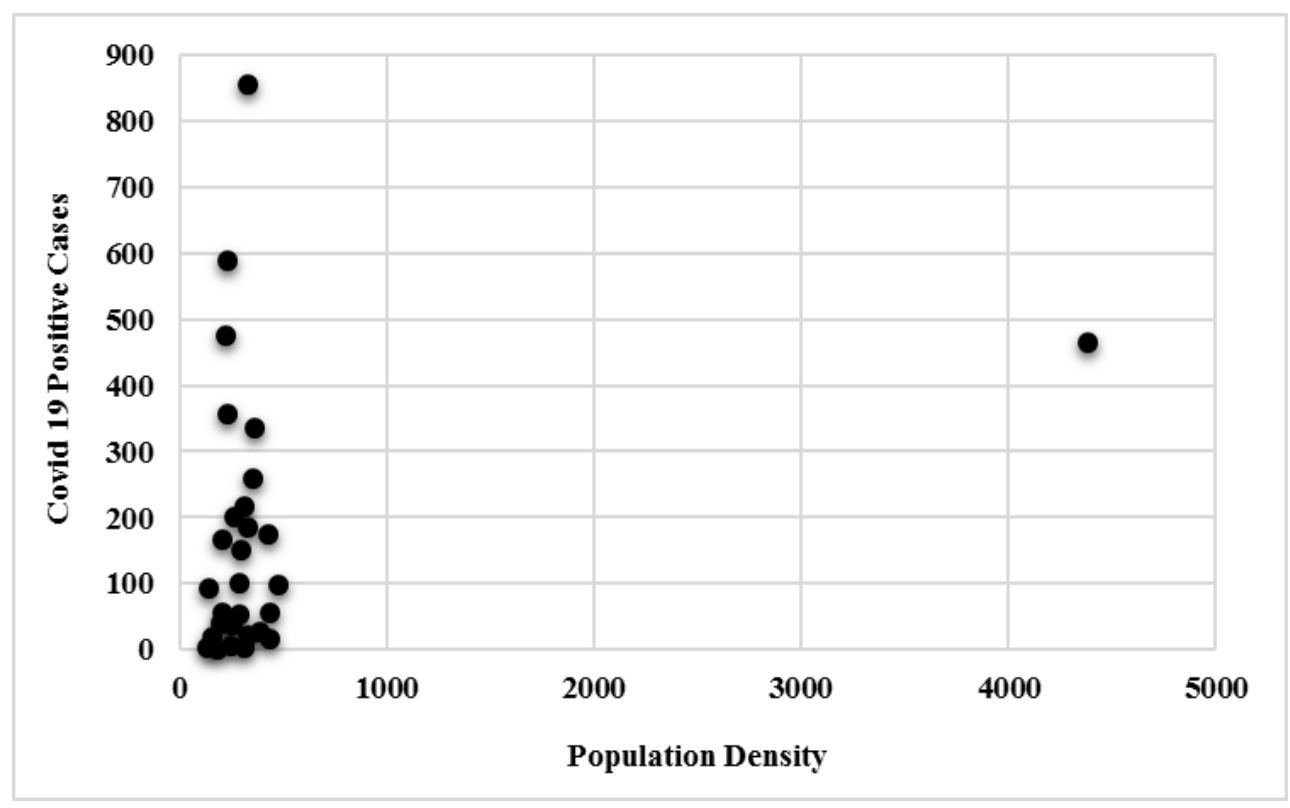

Figure 6b. Scatter plot between population density and COVID-19 cases for Karnataka state

Source: Prepared by authors

\section{Telangana state}

Telangana state has observed a spike in the number of COVID-19 cases on daily basis. Currently, the state has infected by 3496 persons and out of this infected 1710 persons recovered and 123 persons got deceased. This state has 3.52 percent mortality rate which is highest in south India and also above the national average 2.82 percent. It is also observed that Hyderabad district has the highest COVID-19 cases within the state which is about 60 percent and also has a high population density 680 persons per sq. $\mathrm{km}$. We have utilized a prospective space-time correlation analysis to detect severely affected districts of COVID-19 in the Telangana. A strong correlation is found between the number of COVID-19 cases and the density of different districts. 


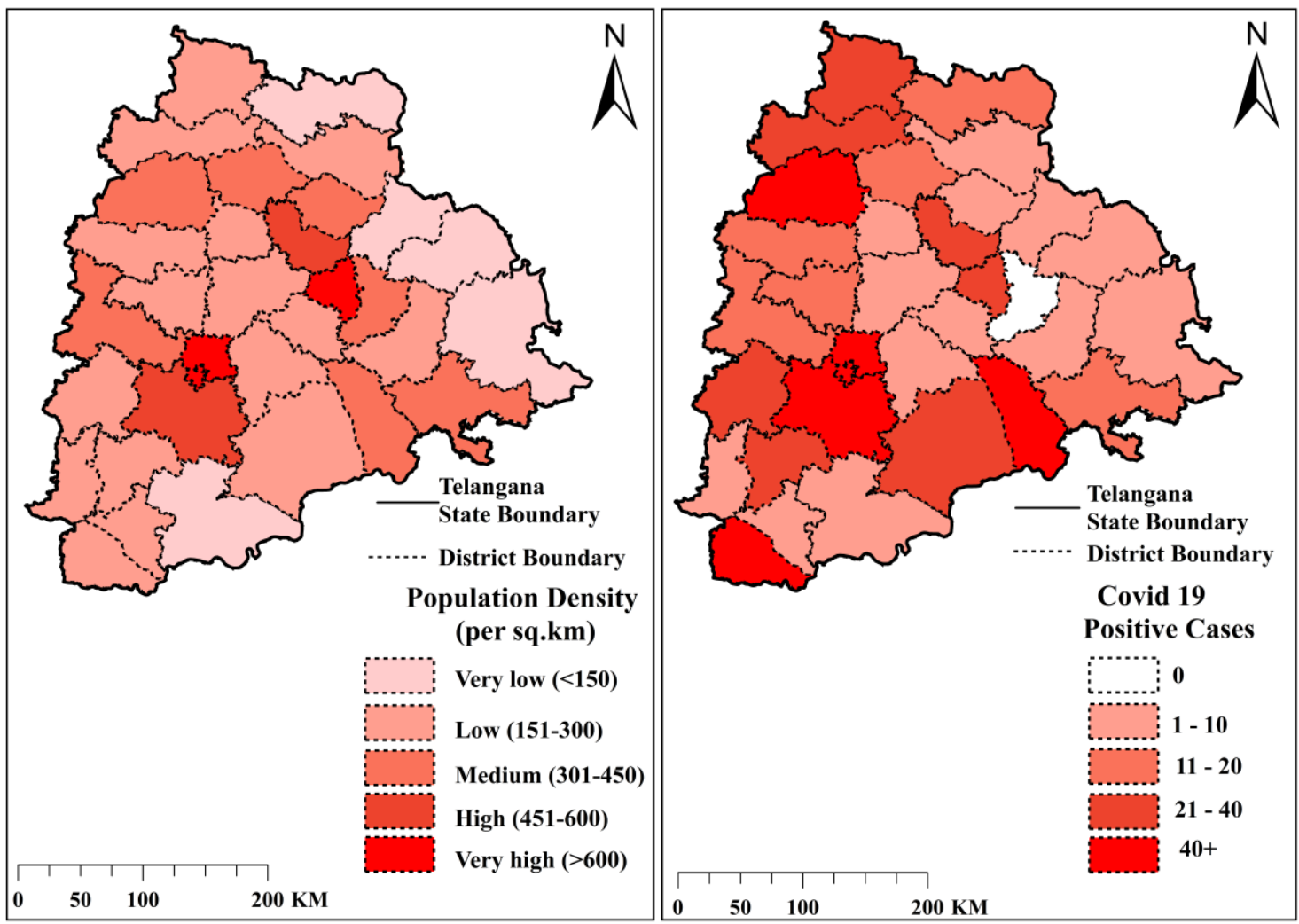

Figure 7a. Spatial distribution of population density and COVID-19 cases in Telangana state

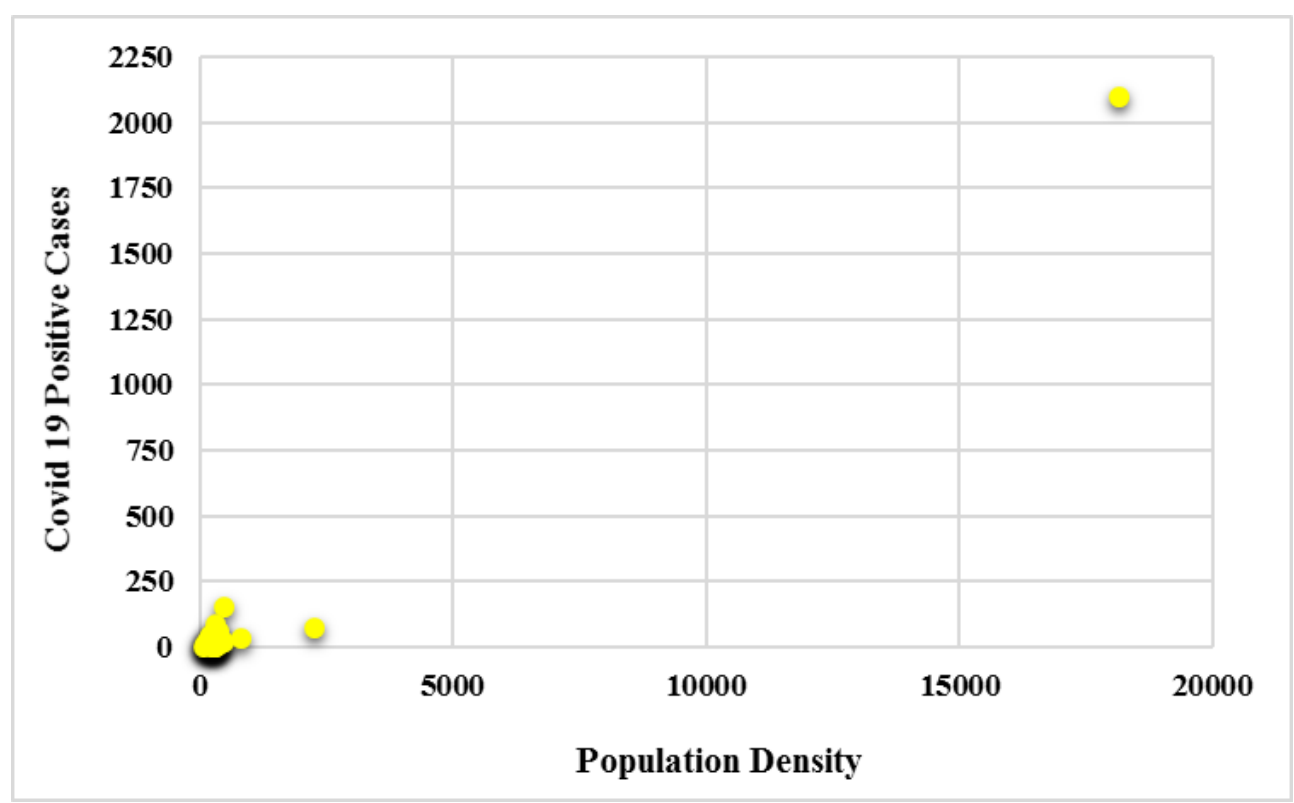

Figure 7b. Scatter plot between population density and COVID-19 cases for Telangana state

Source: Prepared by authors 


\section{Andhra Pradesh state}

Coronavirus is spreading in Andhra Pradesh in despite of the lockdown with 3588 positive cases till $6^{\text {th }}$ June 2020 . The percentage of discharged persons and the fatality rate are 65 percent and 2.03 percent respectively. Kurnool, Guntur and Krishna districts are maximally infected among thirteen districts in the state. Among all south Indian states, Andhra Pradesh has the lowest population density with 304 persons per sq. km. Figure 8a shows the spatial distribution of corona positive cases and demographic density in the state. The dark red colour shows a higher population density and high COVID-19 cases. We didn't find any meaningful association of population density with corona infections for this state.

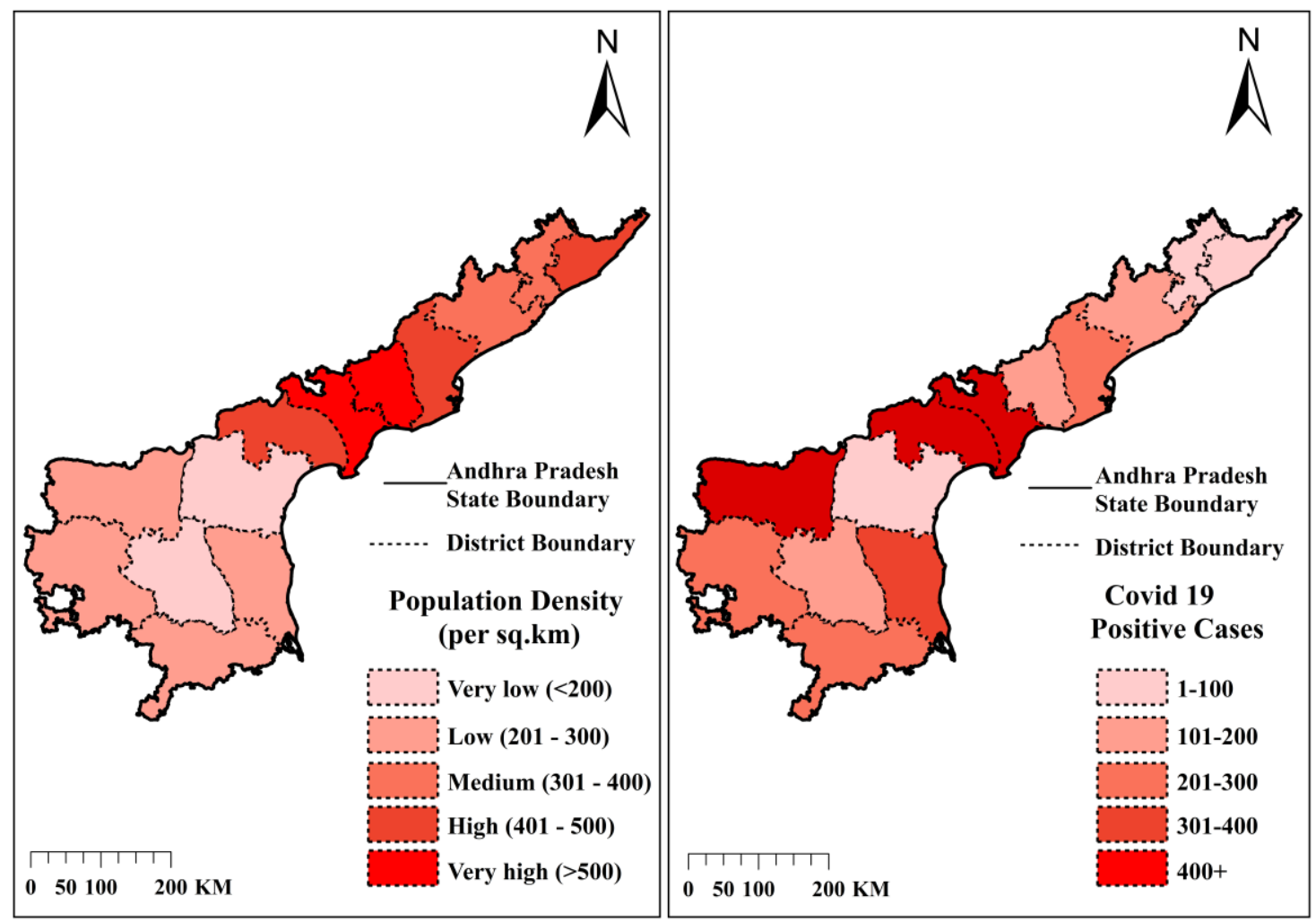

Figure 8a. Spatial distribution of population density and COVID-19 cases in Andhra Pradesh state 


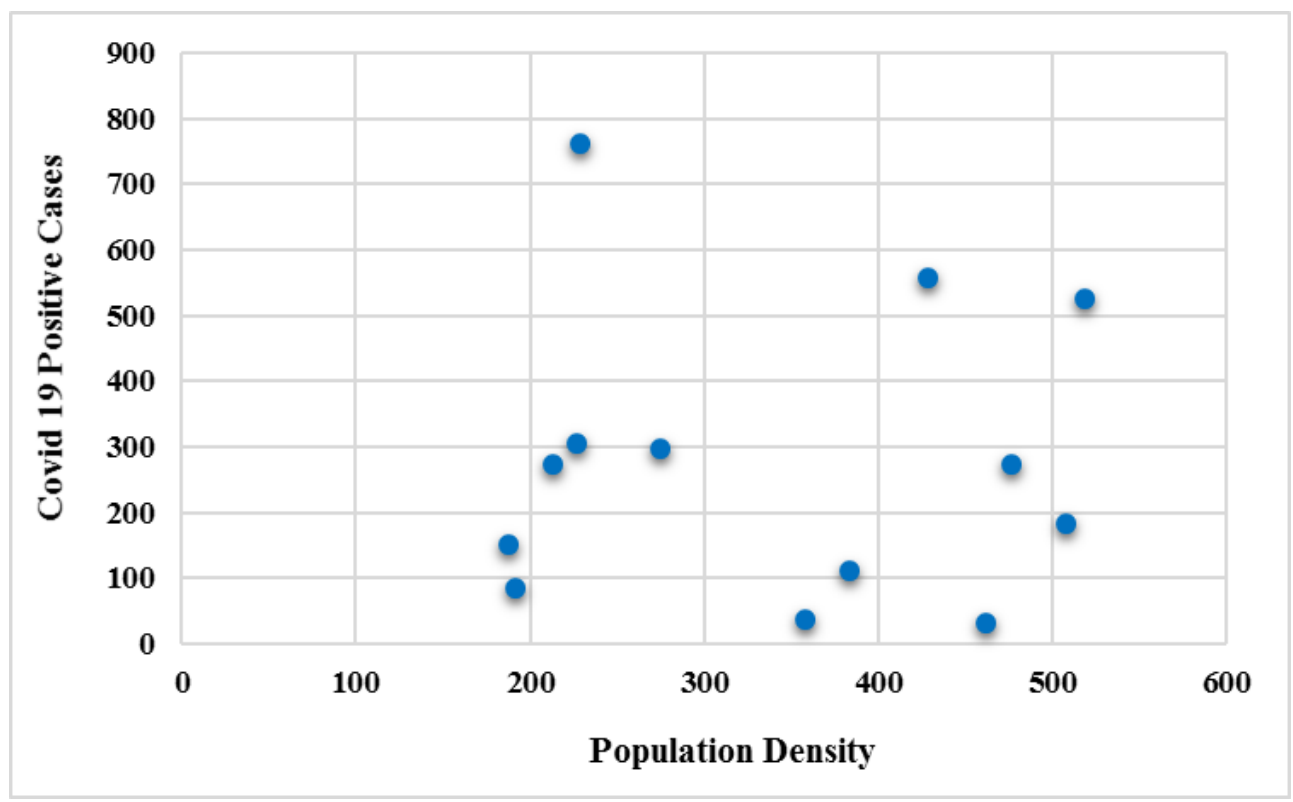

Figure 8b. Scatter plot between population density and COVID-19 cases for Andhra Pradesh state

Source: Prepared by authors

\section{Conclusions}

This paper examines publicly available data from the COVID-19 India portal and state government portals to detect emerging space-time distribution of COVID-19 contagion for different districts. Our results from data accumulated from the five south Indian states illustrate the significance of the relationship between population density and corona positive cases. Regarding the inter-district spatial analysis from south Indian states, we observe that the population density better explains the contagion effect. However, the population density of Kerala and Andhra Pradesh state did not reflect on corona transmission. We find that the positive correlation coefficients that represent the infectious effects from Tamilnadu, Karnataka and Telangana states. Confirmed case numbers are insufficient to recognize the true nature of the COVID-19 pandemic. However compiling data sets which include suspected, potential and negative test numbers can significantly boost monitoring efforts and our understanding of the transmission dynamics COVID-19. ${ }^{[33,34]}$ Despite the significance of our study, it's important to mention limitations. A key limitation of the study is that, even within this nine week sampling duration, we are not able to disassociate the effects of each of the strict steps taken. Another constraint is that the case data contains only confirmed cases, thus it is important to note that possible and suspected cases are not included because of lack of availability. The true character of the COVID-19 pandemic will not be understood for some time. Lastly, there are many districts that were included in the analysis that did not have any positive cases of COVID-19. 
We understand the importance of maintaining observation on emerging and active districts during pandemics, effectively ignoring preceding districts that do not present a serious threat to public health. In addition, the sharing and availability of data are very important and enables a variety of researchers to contribute to their knowledge of COVID-19 in general. Demographers can play a crucial role in mitigating the spread of diseases.

\section{References}

1. Huang C, Wang Y, Li X, Ren L, et al. Clinical features of patients infected with 2019 novel coronavirus in Wuhan, China. Lancet. 2020;395(10223), 497-506. doi:10.1016/S0140-6736(20)30183-5.

2. Lin Q, Zhao S, Gao D, et al. A conceptual model for the coronavirus disease 2019 (COVID-19) outbreak in Wuhan, China with individual reaction and governmental action. International Journal of Infectious Diseases, 2020;93:211216. doi:10.1016/j.ijid.2020.02.058

3. Cheng ZJ, Shan J. novel coronavirus: where we are and what we know. Infection. 2019; 2020:1-9. doi:10.1007/s15010-020-01401-y.

4. World Health Organization (WHO). 2020a. Considerations for Quarantine of Individuals in the Context of Containment for Coronavirus Disease (COVID19): Interim Guidance. https://www.who.int/publications/i/item/considerationsfor-quarantine-of-individuals-in-the-context-of-containment-for-coronavirusdisease- (covid-19). Accessed June 6, 2020.

5. World Health Organization (WHO). 2020b. Critical Preparedness, Readiness and Response Actions for COVID-19. https://www.who.int/publications/i/item/critical-preparedness-readiness-andresponse-actions-for-covid-19. Accessed June 6, 2020.

6. John Hopkins University. Coronavirus Resource Center. https://coronavirus.jhu.edu/map.html. Accessed June 6, 2020.

7. World Health Organization (WHO). Coronavirus disease (COVID-2019) situation reports (Report 138; June 6, 2020). https://www.who.int/emergencies/diseases/novel-coronavirus-2019/situationreports. Accessed June 6, 2020.

8. Arora NK, Mishra J. COVID-19 and importance of environmental sustainability. Environmental Sustainability. 2020. doi:10.1007/s42398-020-00107-z

9. Dooley B, Inoue M. Can Japan's Economy Get Any Worse? It May Soon Find Out. New York Times. March 2020. https://www.nytimes.com/issue/todayspaper/2020/02/25/todays-newyork-times. Accessed June 6, 2020. 
10. Rawat M. Coronavirus in India: tracking country's first 50 COVID-19 cases; what numbers tell. India Today. March 12, 2020. https://www.indiatoday.in/india/story/coronavirus-in-india-trackingcountry-sfirst-50-covid-19-cases-what-numbers-tell-1654468-2020-03-12. Accessed June 6, 2020.

11. Kaushik S, Kaushik S, Sharma Y, Kumar R, Yadav JP. The Indian perspective of COVID-19 outbreak. VirusDisease. 2020. doi:10.1007/s13337-020-00587-x

12. Coronavirus Outbreak in India. https://www.covid19india.org/. Accessed June 6, 2020.

13. Ministry of Health and Family Welfare (MoHFW). 2020b. National guidelines for infection prevention and Control in healthcare facilities. https://main.mohfw.gov.in/diseasealerts/novel-corona-virus. Accessed June 6, 2020 .

14. Census of India 2011. https://censusindia.gov.in/2011Common/CensusData2011.html. Accessed June 6, 2020.

15. Singh KD, Goel V, Kumar H, Gettleman J. India, Day 1: World's Largest Coronavirus Lockdown Begins. New York Times. March 25, 2020, https://www.nytimes.com/2020/03/25/world/asia/india-lockdowncoronavirus.html. Accessed June 6, 2020.

16. Khosravi M. Perceived Risk of COVID-19 Pandemic: The Role of Public Worry and Trust. Electronic Journal of General Medicine, 2020; 17(4). doi:10.29333/ejgm/7856

17. Census of India 2001. https://censusindia.gov.in/2011Common/VitalStatistics.html. Accessed June 6, 2020.

18. Statistical Year Book 2017. Directorate of Economics and Director Statistics, Telangana. https://www.telangana.gov.in/PDFDocuments/Statistical-Year-Book2017.pdf. Accessed June 6, 2020.

19. Districts at a Glance, Andhra Pradesh 2018. https://core.ap.gov.in/CMDashBoard/Download/Publications/District\%20at\%20 Glance\%20-\%202018.pdf. Accessed June 6, 2020.

20. Health \& Family Welfare Department: Government of Tamil Nadu. Tamilnadu COVID 19 Public Dashboard Website. https://nhmtn.maps.arcgis.com/apps/opsdashboard/index.html\#/095ad0a1c0254b 058fa36b32d1ab1977. Accessed June 6, 2020.

21. State Disaster Management Authority: Government of Karnataka. Karnataka COVID 19 Dashboard Website. https://covid19.karnataka.gov.in/coviddashboard/dashboard.html. Accessed June 6, 2020. 
22. Telangana Fights Corona (COVID-19): Government of Telangana Website. https://covid19.telangana.gov.in/. Accessed June 6, 2020.

23. Health, Medical and Family Welfare Department. COVID-19 Andhra Pradesh Website. http://hmfw.ap.gov.in/covid_dashboard.aspx. Accessed June 6, 2020.

24. Government of Kerala Dashboard. Official Kerala COVID-19 Statistics Website. https://dashboard.kerala.gov.in/. Accessed June 6, 2020.

25. Chandra S, Kassens-Noor E, Kuljanin G, Vertalka J. A geographic analysis of population density thresholds in the influenza pandemic of 1918-19. International journal of health geographics, 2013; 12(1), 9.

26. Rocklöv J, Sjödin H. High population densities catalyse the spread of COVID19. Journal of Travel Medicine. 2020; 27(3). doi:10.1093/jtm/taaa038.

27. National Health Profile 2019. Ministry of Health \& Family Welfare Web site. http://www.cbhidghs.nic.in/showfile.php?lid=1147. Accessed May 10, 2020.

28. Environmental Systems Research Institute (ESRI) 2017. ArcGIS Release 10.2.1. Redlands, CA.

29. Kowalski CJ. On the effects of non-normality on the distribution of the sample product-moment correlation coefficient. Journal of the Royal Statistical Society: Series C (Applied Statistics), 1972; 21(1), 1-12.

30. Gautam S, Hens L. SARS-CoV-2 pandemic in India: what might we expect? Environment, Development and Sustainability. 2020; 22(5): 3867-3869. doi:10.1007/s10668-020-00739-5

31. Lakshmi K, Josephine SM. What turned Koyambedu, Chennai's popular wholesale complex market, into a COVID-19 hotspot?. The Hindu. May 10, 2020. https://www.thehindu.com/news/national/tamil-nadu/coronavirus-whatturned-koyambedu-chennais-popular-wholesale-complex-market-into-a-covid19-hotspot/article31546292.ece. Accessed May 10, 2020.

32. Poovanna S. Karnataka sees highest number of Covid-19 deaths in 24 hrs, case count at 4,320. livemint. June 5, 2020. https://www.livemint.com/news/india/karnataka-sees-highest-number-of-covid19-deaths-in-24-hrs-case-count-at-4-320-11591294777559.html. Accessed June 6, 2020.

33. Lipsitch M, Swerdlow DL, Finelli L. Defining the epidemiology of Covid-19studies needed. $N$ Engl $J$ Med. 2020; 382(13): 1194-1196. doi:10.1056/nejmp2002125

34. Gandhi M, Yokoe DS, Havlir DV. Asymptomatic Transmission, the Achilles' Heel of Current Strategies to Control Covid-19. N Engl J Med. 2020; 382(22): 2158-2160. doi:10.1056/NEJMe2009758 